\title{
Empowerment of the Sumbawa Youth Group in the Activity of Catfish and Squash Integrated Cultivation
}

\author{
Neri Kautsari \\ \{nerikautsari040185@gmail.com\} \\ Universitas Samawa, Sumbawa Besar, 84313, Indonesia
}

\begin{abstract}
The demand for catfish in Sumbawa Regency continues to increase, but its production is very low so that to meet the needs, catfish are imported from other regions. One factor in the low production of catfish in Sumbawa Regency is the small number of catfish farming businesses. The lack of the number of businessmen is caused by a lack of knowledge and skills of the community in catfish farming. Therefore, it is necessary to improve catfish farming skills through training activities so that the community can conduct independent cultivation as well as the catfish supply in Sumbawa Regency can be fulfilled from the production in the region. This training consists of several stages, namely the stages of counseling, training \& mentoring (consisting of land preparation, making tarpaulin ponds, stocking seeds, maintenance, handling diseases until harvesting), and evaluating the results of the activities. The training results show that community groups have been able to cultivate as indicated by the amount of catfish production produced at $392 \mathrm{Kg}$ with total income of $\mathrm{Rp} 7.720 .000$ and the value of $\mathrm{R} / \mathrm{C}$ ratio $>1$ (feasible business to run).
\end{abstract}

Keywords: Cultivation, Catfish, Sumbawa

\section{Introduction}

In the past few years, the need for fish in Sumbawa has increased both for freshwater and marine fish. This is due to an increase in the number of people accompanied by an increase in the number of restaurants and lesehan (the concept of eating while sitting on the floor and using low table) which serves fish menus such as fish and fresh vegetables, fish meatballs, and some other culinary-based fish. One of the fish that is popular with the people around Sumbawa Regency is catfish which are included in the species Clarias sp. By the Sumbawa community, this fish is called the local name "simir". Catfish are usually processed into traditional Sumbawa food called "sepat" and are usually almost consumed every day by most Sumbawa people. The high public interest in fish causes the demand for catfish to increase from time to time. In contrast to the number of requests that continue to increase, catfish production in Sumbawa Regency is actually very low. Low catfish production causes the people engaged in the catfish business starting from fresh catfish traders and catfish processing traders to bring catfish from other regions. The survey results in several markets in Sumbawa show that most of the catfish on the market are imported from Lombok Island and several other areas. This condition causes the price of catfish to be more expensive because of the addition of transportation costs and other costs. In addition, the distance between Lombok 
and Sumbawa which is classified as far away can result in a decrease in the quality of catfish and consequently results in a decrease in the subsequent quality.

One of the factors causing low catfish production in Sumbawa Regency is the small number of businessmen engaged in the cultivation of freshwater fish including catfish. The lack of the number of businessmen is largely due to the lack of knowledge and skills of the people in catfish farming. Even if viewed from the potential of the land, the level of ease of cultivation and the prospect of the catfish market, this business can be said to be very feasible to be carried out in several locations in Sumbawa Regency. Based on the problems and the potential, a solution is needed that can increase catfish production by utilizing the existing potential and empowering the surrounding community. This catfish farming training is carried out as an effort or solution to increase the knowledge and skills of community groups in catfish farming. With the increase in cultivation knowledge and skills, it is expected that community groups can conduct independent cultivation so that the supply of catfish in Sumbawa Regency can be fulfilled from production in the region. Another expectation is that with the skillful community in conducting catfish cultivation business can be an alternative livelihood opportunity that can increase people's income and reduce unemployment. Catfish cultivation with an emphasis on empowering local communities is known as the bottom-up approach [1]

The cultivation technique trained in this activity is the cultivation of tarpaulin ponds integrated with squash cultivation. The selection of tarpaulin pond cultivation is due to the cultivation techniques that are quite easy to do by beginners and have quite affordable capital. The integration with squash is carried out for several reasons, namely 1) squash which is propagating will be able to minimize the heat of the sun entering the pond so that the pool water temperature is more optimal to support the growth of the catfish; 2) the integration with squash is also an effort to optimize the land potential (two products in one field); 3 ) increasing farmer's income; 4) squash is one type of vegetable that is in demand by the people of Sumbawa.

\section{Methods}

The methods used in this activity were training and mentoring. Training and mentoring were implemented in several stages of activities carried out in a structured and systematic manner. In general, this activity consists of three stages of activity namely 1) counseling activities; 2) training \& mentoring, and 3) evaluation. In detail, the forms and benefits of each stage of activity are as follows:

\subsection{Counseling of Catfish Cultivation and Its Integrity with Squash}

Counseling was the first step taken in this activity and carried out in the form of material delivery related to catfish farming and its integration with squash. Some of the materials presented in this counseling were related to the purpose of cultivation, cultivation techniques, and the benefits of doing cultivation. The purpose of this stage of counseling is to add and improve insight, provide motivation, and change the mindset of the target community groups. This goal is in accordance with the definition of education, namely the efforts made to encourage behavioral changes in individuals, groups, communities, or communities so that they know, want and are able to solve the problems faced. According to [2] , the main purpose 
of agricultural counseling is to increase the agricultural yields for both the interests of colonizers and indigenous interests.

\subsection{Training and Mentoring}

In this activity, training and mentoring were carried out using the method of active participation. The active participation referred to in this activity is a group of young people (communities) actively practicing directly in the catfish and squash cultivation starting from land preparation activities to marketing activities. Active community participation is something that must be emphasized in empowerment because it is the people who will enjoy the results and as an effort so that the target community groups can understand in depth about the training materials provided. Participation is defined as voluntary contributions from the community to the project without participating in decision making[2]. The stages of training and assistance as well as forms of community group participation in each of these activities are as follows:

\section{a. Land preparation training}

Land preparation is one of the important factors in supporting the success of freshwater fish cultivation including catfish. Therefore, land preparation training is the basic training carried out to the target community groups. This training aims to train target groups in selecting and preparing suitable land for catfish and squash cultivation. Good land is land that can support the availability of water both in quantity and quality, protected land from pests, is easily accessible and monitored, has a flat or sloping topography, and is not rocky. In this training activity, community groups were trained to recognize the type of land suitable for catfish and squash cultivation. In addition, youth groups were also trained in land preparation starting from land clearing to the ground level distribution. The method used in this training was active participation, namely the youth group actively preparing land starting from the introduction of location to land clearing (Figure 1).

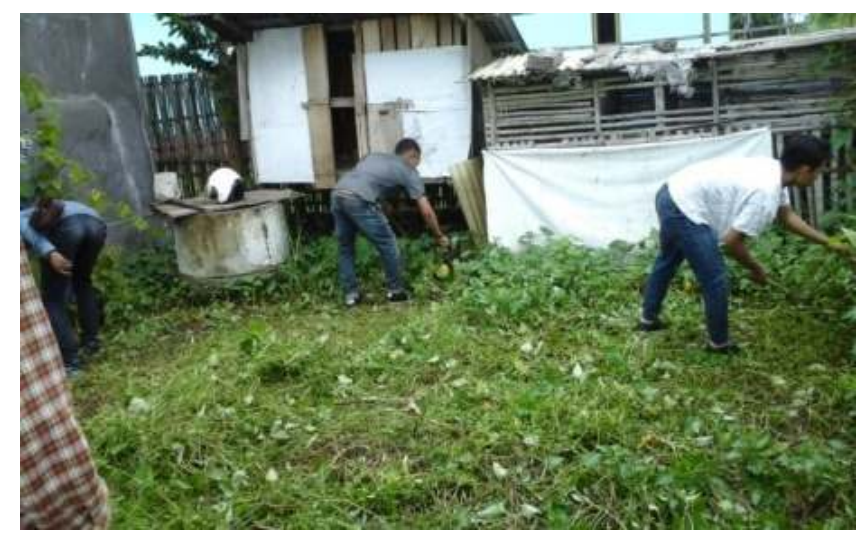

Fig. 1. Preparation and Cleaning of Cultivation Areas

Land clearing was done by clearing land from grass (other plants) and rocks or other objects that are thought to cause leaks in the tarpaulin pond to be made. Land preparation was also carried out by leveling the land by using husks and loosening the soil around the pond that would be used for planting squash. Land preparation also included the excavation of land to facilitate the installation of ponds and the planting of squash seeds. 


\section{b. Tarpaulin Pool Making Training}

After the land preparation training, the youth group was then given a training in making tarpaulin pools. The pool made in this training was a tarpaulin pool above the ground. According to [3] , the benefits of using tarpaulin ponds can be applied to dry, easy and inexpensive land done by farmers, and increasing farmers' income. The size of the tarpaulin pool made was $2 \times 3 \times 1$ meter and made of 2 ponds (Figure 2)

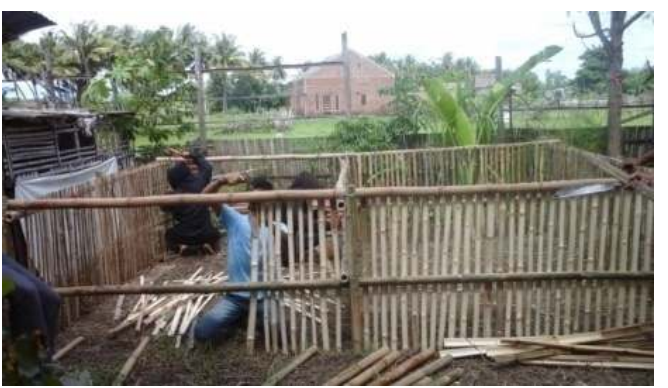

(a)

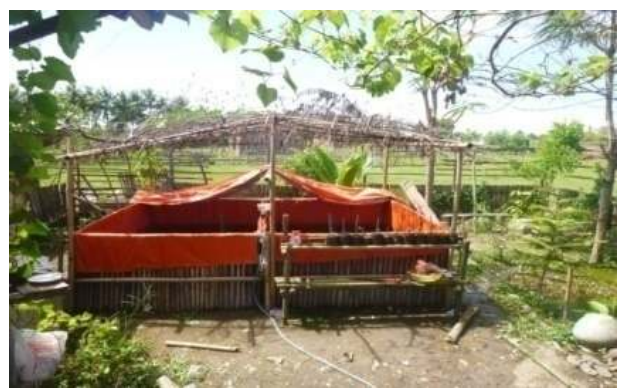

(b)

Fig. 2 Tarpaulin Pool Making Training. (a) tarpaulin pond frame; (b) tarpaulin pools

\section{c. Training on the selection of good quality catfish and squash seeds}

Training on the introduction of good quality catfish and squash seeds was carried out with the aim that the youth group clearly knew the characteristics of good quality catfish seeds to be cultivated. This is very important because the quality of the seed greatly influences the success of the cultivation. According to [4], to support the success of fish farming, one of the determining factors is the availability of seeds that meet the requirements of the quality, quantity, and continuity[4]. The seeds that are available in large quantities but have low quality will only burden farmers because the results are not balanced with the quantity of feed provided. While the seeds are of good quality but the number is limited, it will not increase the production of the enlargement business, because there will be a shortage of seeds that is quite serious.

Training was carried out by verbal delivery and direct observation of the characteristics of good catfish seeds. The characteristics of good catfish seeds are: 1) having an aggressive movement; 2) uniform size; 3 ) originating from a quality parent; 4) body color is bright and shiny.

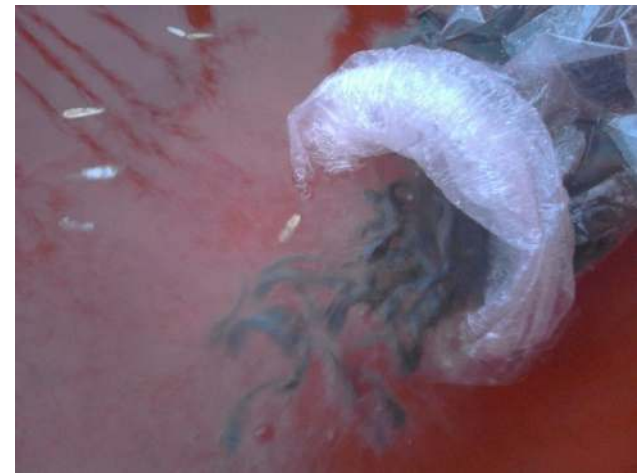

Fig. 3 Catfish Seeds 
The seeds used during the training were seeds originating from hatchery business in Rhee District, Sumbawa Regency and were the area closest to the cultivation location. The distance between the location of hatchery and enlargement is one of the factors that can affect the survival of catfish seeds. If the distance is too far, the catfish seeds have the potential to experience stress caused by a lack of oxygen, an increase in temperature and a shock during the trip.

\section{d. Water Preparation Training as Media for Maintenance and Distribution of Catfish Seeds}

In fish farming, water quality is one of the important factors that influences the survival of fish cultivated[5]. Therefore, the next training carried out was training in water preparation media for the maintenance and stocking of catfish seeds. The training aims to enable youth groups to know firsthand the methods or techniques of water preparation for maintenance media as well as how to spread the right fish seeds. This training is important because most fish farming often fails due to poor water quality and improper way of spreading seeds, causing fish seedlings to become stressed and then die which in turn causes failure in cultivation.

This training begins with the technique of preparing pond water. Youth groups are trained or taught about the number or height of pond water which is good for the beginning of the spread of catfish seeds. In this activity, the height of the pool water used was $30 \mathrm{~cm}$. The quantity or height of the water in the pond was adjusted to the size of the catfish seeds. Before the seeds were stocked, acclimatization was carried out first by inserting the seeds that were still in the container (plastic bag) into the pond and left for 15 minutes to adjust the temperature of the seed location to the pool temperature as the new environment. The container was tilted and allowed to leave the seed by itself. This was done to prevent stress on the seeds (Figure 4).

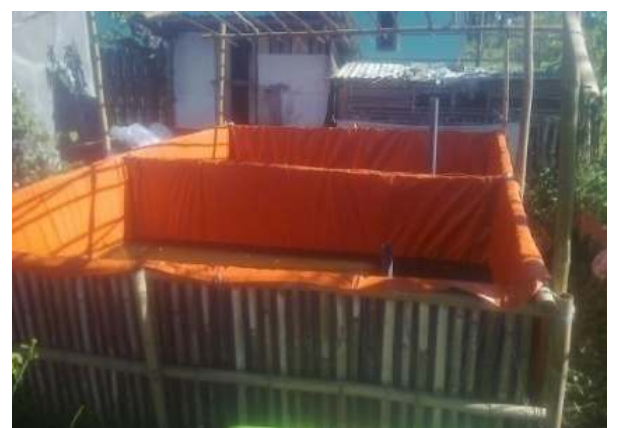

(a)

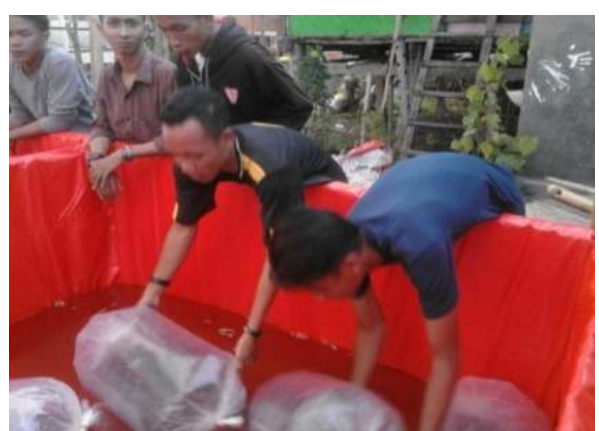

(b)

Fig. 4 Stage of Spreading Catfish Seeds (a) media water preparation; (b) catfish acclimatization

This seeding was carried out in the afternoon so that the temperature of the stocking occurs at the optimum temperature. Although fish can acclimatize at relatively high temperatures, but at a certain degree the temperature rise can cause the death of fish[4]. Drastic changes in temperature to reach $5^{\circ} \mathrm{C}$ can cause stress to fish or kill them.

\section{e. Water Pumpkin Planting Training}


Training on planting squash was conducted from seedlings to planting on the edge of the pond. Squash seeds planted were seeds that have been sown before. In this activity, squash planted around the pond have reached $\pm 10 \mathrm{~cm}$ high. Seed planting was carried out on previously prepared land. The planting hole was made of Portugal and placed next to the parapara pole of squash planting. Squash seeds planting were done in the first two months of the month (Figure 5)

Fig. 5 Squash Planting Process

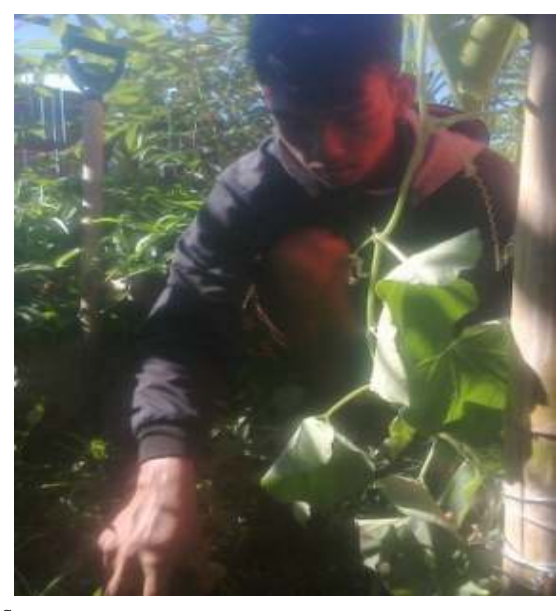

These squash plants are classified as easily planted and their planting areas spread in various parts of the world, from tropical to subtropical regions. Cold highlands and hot lowlands are suitable for squash cultivation[6].

\section{f. Training and Assistance for Maintenance and Catfish and Squash Growth}

Maintenance of catfish starts from stocking the seeds until the stage was ready for harvest. There were two activities that were trained at this stage, namely 1) maintenance and management of catfish feeding; 2) management of water quality and prevention of pests \& diseases. In detail, the stages of each activity were as follows:

1) Maintenance and Management of Catfish Feeding

Fish, like other animals, have a need for feed containing essential nutrients. Some of the essential nutrients needed by fish in supporting their growth are protein, carbohydrates, fats, and vitamins. Errors in determining feed ingredients can have an impact on the low nutrient content and the high cost of providing artificial feed produced. Excessive feeding will cause an increase in the amount of organic matter in the pond which will subsequently break down to form ammonia and pollute the pond environment[3]. The choice of feed containing the right nutrients plays an important role in supporting the growth of catfish. Therefore, training related to feeding needs to be done to increase cultivation production.

At this stage, the youth group was given training related to the selection of types, amount and time of feeding. The right type and amount of feed will have an impact on increasing catfish production. The feed given in this cultivation activity consists of main feed and complementary feed. The main feed given was artificial feed which has good nutritional content. As an effort to accelerate the growth of catfish, in this activity catfish were fed with high protein content $(31-33 \%)$ under the trademark Hi-pro-vite (Figure 6). Protein has an 
important role in regulating the optimal growth of fish including catfish. Decreasing the amount of protein given to catfish will cause its growth to decrease or slow down so that it will affect harvest time[7].
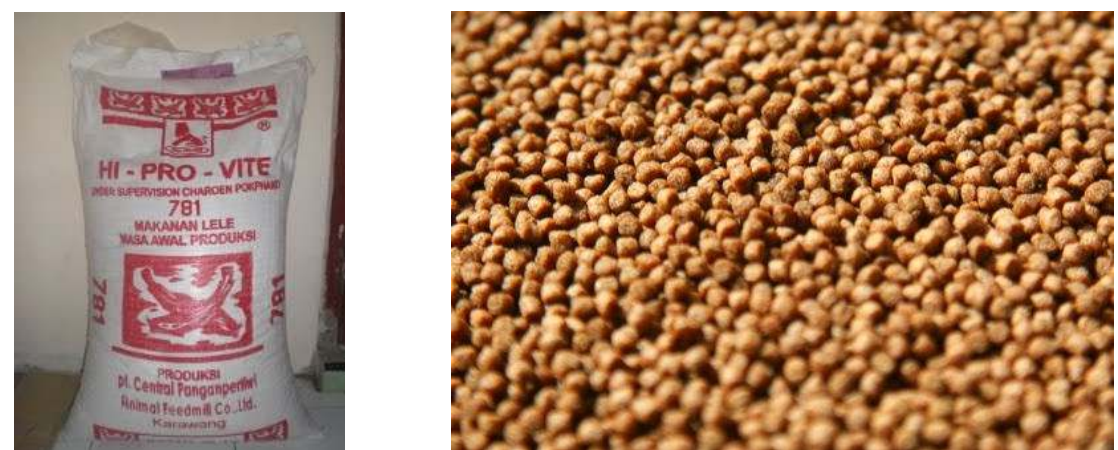

Fig. 6 Types of artificial feed given during the training

Not only for the nutritional content, in feeding the catfish, the size and shape are also must be considered. The size of feed given in this training activity was feed that has a diameter of 1 to $2 \mathrm{~mm}$ and was float. The size of fish mouth openings greatly determines the size of the feed to be given. At the beginning of maintenance, the catfish were given smaller feeds of $1 \mathrm{~mm}$ while after entering the age of 15 days after the stocking, the feed size was increased to $2 \mathrm{~mm}$. The feed given was float because it was adapted to the nature of catfish that feed on the surface of the water. The frequency of feeding was carried out twice a day, in the morning and evening with the feeding time is 5-7 hours. Providing artificial feed during training activities was done using the ad libtum method, which is feeding until full. This method was used to avoid waste of feed and reduce water pollution caused by excess feed residue that enters the waters.

In the training activities, the youth group was also trained in making natural feed fermented with EM-4. This feed was used as a companion feed on catfish. Organic food was made by fermentation of cow dung (the manufacturing process is presented in Figure 7).

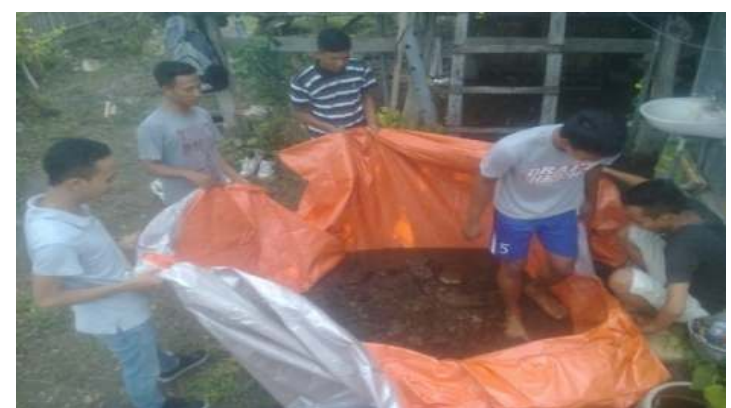

Fig. 7 Stage of making organic feed from cow dung

Explained that fermented feed ingredients can increase nutritional value when compared with the original ingredients[8]. Through processing with fermentation technology by probiotics EM-4, it is expected to be able to increase protein digestibility of feed, protein content of feed and fish weight gain, resulting in an increase in feed efficiency. Explained that 
probiotics which contain microbial decomposers when put into the feed, can increase feed digestibility by the decomposition process carried out by these microbes[9]. According to Higa (1980) in Sudarsana (2000) the use of EM-4 can improve health, growth and quality of fish production. EM-4 consists of photosynthetic bacteria, lactic acid bacteria (Lactobacillus sp.), yeast (Saccharomyces sp.) and Actinomycetes. The use of probiotics has been tried for tilapia which was maintained in the probiotic system would grow optimally at $1.5 \%$ feed level with feed containing 35\% probiotics. The results of the study (Rachmawati et al. 2015) showed that the application of probiotic technology to cultivation media had a better influence on increasing growth in length and weight of Sangkuriang catfish seeds and stability of nursery media[3].

2) Water Quality Management and Handling Catfish Diseases

Catfish is one of the fish that is susceptible to disease. Disease attacks in cultivation can reduce the number of survival rates in fish and even cause crop failure. Therefore, the handling of fish pests and diseases needs to be known by youth groups of trainees. At this stage, youth groups were trained to recognize the characteristics of fish that were affected by the disease and how to deal with it. Observations of pests and diseases that attack catfish were carried out every day by sorting fish in the pond. During these activity, there have been found several diseases that attacked the catfish while the pests were not found. In the first month to the second month, the catfish which were kept by the youth group, did not show any signs of being attacked by the disease, but entering the third month, the catfish exhibit less aggressive traits and death. The results of the observation showed that catfish that experienced death and decreased appetite had the characteristics of a red head, skin peeling and the fin part being damaged (Figure 7). The existence of fish that was attacked by the disease makes the group of young people become aware of the characteristics of catfish that were attacked by disease.

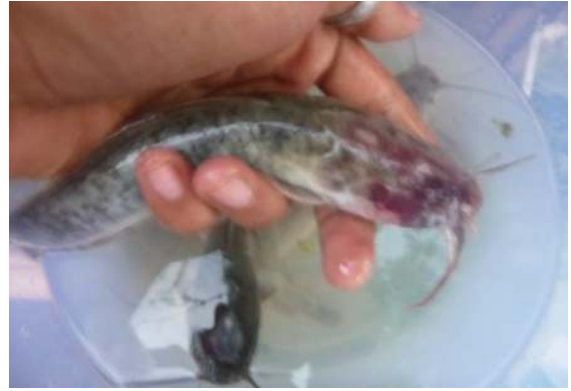

(a)

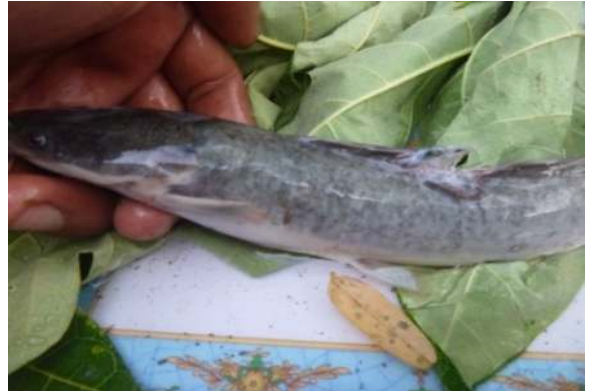

(b)

Fig. 7 (a) red head section; (b) the skin of the fins peels off

The training was then followed by handling fish that had been stricken with the disease by utilizing the ingredients around. Some methods for handling sick fish trained in this activity were soaking with salt water, papaya leaves and noni (Figure 8). Besides being able to cure diseases, the enzyme papain contained in papaya can also increase feed digestibility. The results of the study showed that the papain enzyme in papaya was able to increase protein digestibility in fish so as to increase the survival of fish[10]. 


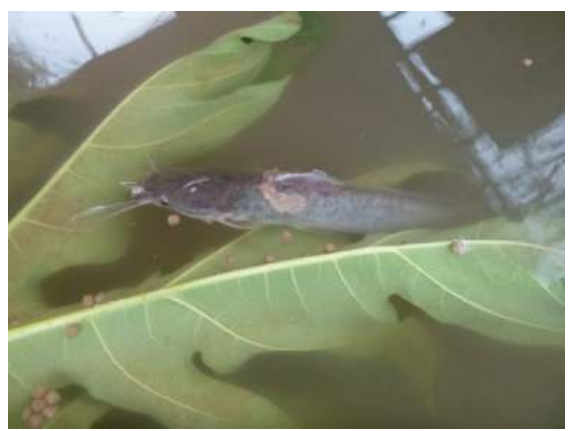

(a)

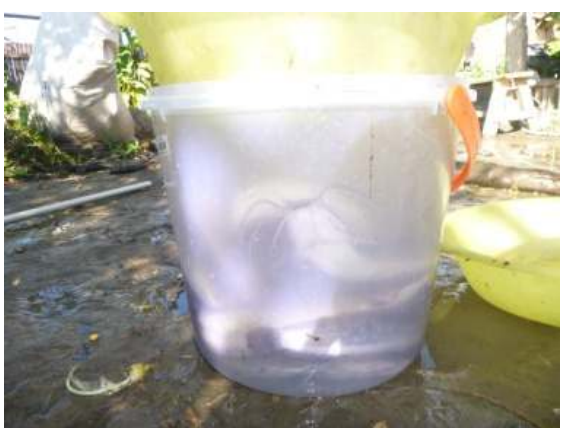

(b)

Fig. 8 Treatment of catfish caught in disease. (a) soaking in papaya leaves; (b) soaking in a salt solution

Fish that have been attacked by the disease are separated from the enlargement pond. This was done to prevent transmission of disease to other fish. Diseased fish were then transferred into a basin and soaked fifteen minutes in a solution of salt and papaya leaves. After that, the fish was transferred to a soil pond measuring $1 \times 0.5 \times 0.5 \mathrm{~m}$. From the treatment, obtained satisfactory results, the fish treated gradually showed aggressive and reddish properties on the head faded.

\section{g. Training for Catfish and Squash Harvesting}

Fish harvesting training was carried out by training target groups how to determine harvest weights and how to harvest well. The size of fish harvested during training was in the range of 100 - $125 \mathrm{gr}$. The size was adjusted to the wishes of most consumers. The results of the previous survey showed that the majority of consumers did not like large catfish. In this activity, the youth group was also trained on how to handle several fish problems that had reached harvest time. As for some problems that often occur when fish have reached the size of ready to harvest fish, which were not sold, so if they were kept continuously, they would use excessive feed so that it can increase maintenance capital and even cause losses. Therefore, in this activity, young people were trained in limiting the consumption of feed to fish ready for harvest.

\section{Results}

\subsection{The Production of Catfish and Squash}

The target of catfish production by stocking was 4000 heads was $500 \mathrm{Kg}$ assuming the survival rate (SR) was $75 \%$. At the end of the activity, it was known that the number of deaths in catfish was \pm 155 tails (3.8\% of the total stocking density) thus indicating that the value of survival was $96.2 \%$. The life velocity value indicates that the cultivation carried out by the youth group was classified as successful. Harvested catfish weighs $\pm 100-150$ gr with a body length of $\pm 17 \mathrm{~cm}$. Based on the average weight and survival value of $96.2 \%$, it was assumed that the amount of catfish production in tarpaulin ponds was $577 \mathrm{~kg}$ but at the time of training, the growth of catfish was not uniform so that those who managed to harvest were only 392.8 
$\mathrm{kg}$. The squash produced during the training and mentoring was 15 pieces with weights varying in size from $500 \mathrm{gr}$ to $2 \mathrm{~kg}$ per fruit.

\subsection{Community Group Income Levels from Catfish and Squash}

Catfish that were successfully marketed during training and mentoring activities were $392.8 \mathrm{Kg}$. The selling price per kilogram of catfish is IDR $35,000 / \mathrm{kg}$ so that during the activity, the total income obtained by the youth group was 13,720,000. Based on the total revenue and the amount of expenses incurred during cultivation (IDR 6,000,000), it is known that the income from this business was IDR 7,720,000 in one harvest. The results of the R/C ratio calculation are $>1$, the value indicated that the businessmen were profitable and the business was feasible. In this activity, squash obtained from cultivation was not marketed and was only for personal consumption by youth groups.।

\subsection{Level of Understanding of Community Groups on the Integrated Cultivation of Catfish and Squash}

In this activity, the evaluation of the youth group level of understanding was only carried out by the question and answer method directly at each stage of the activity. The evaluation results showed that all group members have understood and were able to carry out catfish farming. Apart from the results of the question and answer, the results of the understanding were also can be seen from the success of cultivation and group behavior in handling problems that exist during cultivation.

\section{Conclussion}

Integrated catfish and squash training has been able to increase the knowledge and skills of youth groups in conducting integrated cultivation ranging from land preparation activities, pond preparation, media water supply, maintenance, disease management to the harvest. In the future, this training activity needs to be developed through training in marketing and processing catfish products.

\section{References}

[1] Rosalina D. Analisis Kelayakan Usaha Budidaya Ikan Lele di Kolam Terpal di Desa Namang Kabupaten Bangka Tengah. Maspari J. 2014;6(1):20-4.

[2] Sadono D. Pemberdayaan Petani: Paradigma Baru Penyuluhan Pertanian Di Indonesia. J Penyul. 2008;4(1):66-74.

[3] Rachmawati D, Samidjan I, Setyono H. Manajemen Kualitas Air Media Budidaya Ikan Lele Sangkuriang (Clarias gariepinus) dengan Teknik Probiotik Pada Kolam Terpal di Desa Vokasi Reksosari, Kecamatan Suruh, Kabupaten Semarang. PENA Akuatika. 2015;12(1):24-32.

[4] Susanto H. Teknik Kawin Suntik Ikan Ekonomis. Jakarta: Penebar Swadaya; 1996.

[5] Augusta TS. Dinamika Perubahan Kualitas Air Terhadap Pertumbuhan Ikan Lele Dumbo (Clarias gariepinus) yang Dipelihara di Kolam Tanah. J Ilmu Hewani Trop. 2016;5(1):41-4.

[6] Sastrapradja S. Sayur-sayuran. Jakarta: Balai Pustaka; 1980.

[7] National Research Council. Nutrient Requirement of Warmwater Fishes and Sheelfishes. Revised Ed. Washington D.C: National Academy of Sciences; 1983. 102 p. 
[8] Winarno FG, Farsiaz S, Fardiaz D. Pengantar Teknologi Pangan. Jakart: Gramedia Pustaka Utama; 1980. 163 p.

[9] Tangko AM, Mansyur, Reski. Penggunaan Probiotik pada Pakan Pembesaran Ikan Bandeng dalam Keramba Jaring Apung di Laut. Akuakultur. 2007;2:33-40.

[10] Amalia R, Subandiyono, Arini E. Pengaruh Penggunaan Papain Terhadap Tingkat Pemanfaatan Protein Pakan dan Pertumbuhan Lele Dumbo (Clarias gariepinus). J Aquac Manag Technol. 2013;2(1):136-43. 